\title{
Finnes det evidens for at sykepleiefaglig veiledning er nyttig?
}

\section{Veiledning skal bidra til økt bevissthet i yrkesutøvelsen gjennom faglige refleksjoner. Men hva forteller} forskningen om nytteverdien?

\section{Elin Drangsholt}

Intensivsykepleier og ledende spesialsykepleier

Postoperativ og intensivavdelingen, Akuttklinikken, Oslo universitetssykehus, Ullevål

Gry Bruland Vråle

Sykepleiefaglig veileder og førstelektor emerita

VID vitenskapelige høgskole, campus Diakonhjemmet

Anne Marie Saxlund

Sykepleieveileder, gestaltterapeut og leder

Sunn Ledelse

Arbeidsbelastning

Etikk

Kvalitativ studie

Kvantitativ studie

Mestring

\section{Hovedbudskap}

Formålet med denne artikkelen er å beskrive og diskutere hvordan evidensbegrepet brukes når man forsker på sykepleiefaglig veiledning. Det er vanskelig å måle og finne bevis for at sykepleiefaglig veiledning har målbar effekt for deltakerne i en veiledningsprosess. I artikkelen gjør vi rede for forskeres vurdering av evidens i sykepleiefaglig veiledning i fire oversiktsartikler. 
Faggruppen for veiledere i Norsk Sykepleierforbund (NSF) beskriver sykepleiefaglig veiledning som en virksomhet der sykepleiere kan bli kjent med seg selv, bearbeide eget refleksjonsgrunnlag og bevisstgjøre handlingsvalg. Veiledningens mål beskriver faggruppen som det å bidra til kvalitets- og kompetanseutvikling (1).

\section{Mål for veiledning}

For den individuelle sykepleier kan veiledning bidra til $\varnothing \mathrm{kt}$ bevissthet om egen væremåte i yrkesutøvelsen. Væremåte er her forstått hvordan vi forholder oss i yrkesut $\varnothing$ velsen i vid forstand. Det omfatter holdninger og verdier, faglig innsikt og ferdigheter samt egne reaksjoner.

Sett fra et organisasjonsnivå og ledelsesnivå kan veiledning bidra på følgende områder:

- Kvalitetsutvikling - og sikring av virksomhetens mål.

- Kompetanseutvikling innen sykepleietjenesten.

- Faglig inspirerte sykepleiere og et godt arbeidsmiljø, som igjen bidrar til redusert sykefravær.

Kilde: http://digiblad.no/nsf/veilederen/

Vår erfaring er at tilbud om sykepleiefaglig veiledning etter fullført utdanning er ulikt utbredt, og på mange arbeidssteder er veiledning ikke-eksisterende. Tidspress, økonomiske begrensninger og for lite kunnskap om veiledningens betydning kan være noen av årsakene til dette.

\section{Hva er evidens?}

Evidens er det at noe er helt innlysende, et bevismateriale eller resultat av unders $\varnothing$ kelse som st $\varnothing$ tter en antakelse. I filosofisk språkbruk betegner evidens den høyeste grad av visshet man kan ha (2).

Den naturvitenskapelige forståelsen av evidensbegrepet ligger ofte til grunn innen forskning, og da anses bestemte vitenskapelige metoder som mere evident enn andre.

Katie Eriksson (3) hevder at sykepleievitenskapen som en menneskevitenskap trenger et evidensbegrep som er forankret i den humanvitenskapelige tradisjon, ettersom den naturvitenskapelig orienterte evidensforståelsen er for snever. Hun viser også (3) til den tyske filosofen Gadamer som relaterer sannheten til noe som trer frem ved at en bestemt situasjon blir belyst. 
Landsgruppen av veiledere i NSF har i sin handlingsplan fra 2017-19 vedtatt å belyse kunnskapsgrunnlaget for sykepleiefaglig veiledning.

Formålet med denne artikkelen er å beskrive og diskutere bruken av evidensbegrepet i forskning innen sykepleiefaglig veiledning i grupper.

\section{Metode}

Et litteraturs $\varnothing \mathrm{k}$ ble utført i forbindelse med arbeidet med å klargjøre kunnskapsgrunnlaget. Det ble s $\varnothing$ kt etter studier om sykepleiefaglig veiledning i grupper. Søket var avgrenset til engelskspråklige og skandinaviske artikler publisert fra 2008 til 2017. S $\varnothing$ ket ble foretatt i databasene Medline, Cinahl og SweMed+ i november 2017. Det ble også søkt i utvalgte referanselister.

Søkeord var: clinical supervision, group process, group, mentoring, nurse, nursing staff, nursing supervisory, peer group, professional competence.

Søkene ga 189 treff. Etter gjennomlesing av alle abstrakter ble fire systematiske oversiktsartikler og sju primærstudier inkludert i rapporten.

Studier som omhandlet veiledning av studenter, ble ekskludert. Studier på individuell veiledning ble også ekskludert, da disse var vanskelige å skille fra praksisveiledning som kan ha mere form av opplæring.

Resultatet av dette søket er beskrevet i en upublisert rapport (4).

I denne artikkelen er det de fire systematiske oversiktsartiklene $(5,7-9)$ som alle tar opp spørsmålet om evidens for at sykepleiefaglig veiledning har effekt, som danner datagrunnlaget. De $\varnothing$ vrige studiene i rapporten omtaler ikke evidens og er derfor utelatt i denne artikkelen.

\section{Resultater}

I det følgende gjøres det rede for fire oversiktsartikler og forfatternes funn av evidens i sykepleiefaglig veiledning.

Brunero og Stein-Parbury (5) inkluderte tjueto studier i sin artikkel. Forfatterne hevder at det finnes betydelig evidens i litteraturen og tilstrekkelig empirisk st $\varnothing$ tte for implementering av faglig veiledning i sykepleie. 
Inklusjonskriteriene i deres studie var at studiene skulle inneholde en evaluering av veiledningens effekt, og at både tilnærmingen til veiledning og metode for datasamling var klart beskrevet. Utvalget domineres av veiledningsgrupper for sykepleiere innen psykisk helsearbeid og eldreomsorg.

Resultatene er kategorisert etter Proctors modell (6) for veiledningen. Denne modellen beskriver en styrkende, en normativ og en formativ funksjon av veiledning. Forfatterne hevder det kan påvises evidens knyttet til alle funksjonene, men tydeligst i den styrkende funksjonen ved at veiledning gir kollegastøtte og reduserer stress.

Den normative funksjonen viser seg ved at veiledning fremmer profesjonell og faglig utvikling, og den formative veiledningen ved at veiledning har effekt på utvikling av fag og ferdigheter.

Francke og de Graaff (7) hevder i sin studie at det til tross for mange indikasjoner på at gruppeveiledning for sykepleiere har effekt, så begrenses den empiriske evidensen av at de 17 studiene som inngår i deres utvalg, er både ulike og av varierende kvalitet.

\section{$\equiv \ll$ Kun fire av studiene ble av forfatterne vurdert til å ha høy kvalitet.»}

Inklusjonskriteriene innebar krav om beskrivelse av veiledningsprogrammet og av gruppeveiledningens effekt på sykepleiere eller utbytte for pasienter. Kun fire av de inkluderte studiene ble av forfatterne vurdert til å ha høy kvalitet. De øvrige studiene var små, og forfatterne benyttet ulike måleinstrumenter og ulike variabler for å beskrive resultatene.

Mange forfattere benyttet egenproduserte spørreskjemaer der validitet og reliabilitet ikke var vurdert. Det var stor variasjon i antall veiledninger. Forfatterne hevder at en sterk vitenskapelig evidens kun kan fremskaffes når tilfredsstillende design og sammenliknende variabler og metoder anvendes i forskningen. 
Dilworth og medarbeidere (8) inkluderte 59 studier i sin oversiktsartikkel. Artikkelen identifiserer pågående diskurser og eksisterende evidens i veiledning av sykepleiere.

Forfatterne sier at i dagens debatter om veiledning er de viktigste temaene mangel på beviselig effekt grunnet veiledningens komplekse natur, og motstand i helseorganisasjoner på bakgrunn av tid, bemanning og økonomi.

Dilworth og medarbeidere peker både på at manglende konsensus om hva veiledning er, og på at ulike forventninger til veiledningens utbytte gjør det vanskelig å finne effekt av veiledningen. Her spriker også forskningen i mange retninger fordi studiene legger vekt på ulike sider av veiledning som middel til å redusere stress, gi kollegast $\varnothing t t e$, redusere utbrenthet, iverksette retningslinjer, bedre pasientsikkerhet og skape felles forståelse.

Til tross for mye forskning er det derfor liten statistisk påviselig effekt. Veiledning er en kompleks intervensjon, og forfatterne stiller spørsmål ved om den i det hele tatt er egnet for empirisk forskningsdesign.

\section{Motstand mot veiledning}

Forfatterne hevder å påvise at det ofte forekommer motstand mot veiledning fra sykepleiernes side. Forfatterne forklarer motstanden fra sykepleierne med at veiledningstilbud som legges utenom arbeidstiden, kan oppfattes som mindre viktig siden det ikke er en integrert del av arbeidet som sykepleier. Videre kan det kjennes urimelig for sykepleierne å møte opp på veiledning i egen fritid.

Forfatternes konklusjon er at sykepleiefaglig veiledning har et diffust evidensgrunnlag og begrenset kvantitativ evidens.

Konklusjonen begrunner de med at det knytter seg forvirring til veiledningens rolle og struktur.

\section{三 «De hevder at det på grunn av ulike kontekster ikke er mulig å ha en felles forståelse og lik implementering av veiledning.»}

De argumenterer likevel for at det finnes mye kvalitativ forskning som viser positive effekter, som $\varnothing \mathrm{kt}$ arbeidstilfredshet, redusert stress og opplevd st $\varnothing t t e$. De hevder at det på grunn av ulike kontekster ikke er mulig å ha en felles forståelse og lik implementering av veiledning. 
Videre hevder de at sykepleiefaglig veiledning må forankres lokalt slik at komplekse kontekstuelle faktorer kan anerkjennes.

Pollock og medarbeidere (9) sin oversiktsartikkel inneholder både kvantitative og kvalitative studier, deriblant studiene til Brunero og Stein-Parbury (5), Francke og de Graaff' (7) og Dilworth og medarbeidere (8).

Formålet med studien var å måle effekt av klinisk veiledning som intervensjon. Forfatterne knytter sine forskningsspørsmål til evidens og nøkkelkomponenter i veiledningsintervensjoner. Bakgrunnen for studien var en planlagt endring av lovpålagt veiledning for jordm ødre i Storbritannia. Studien fungerte som et ledd i utforskning av alternative modeller for veiledning.

Utvalget inkluderte ti systematiske litteraturstudier og nitten primærstudier. Gjennomgang av studiene synliggjorde både en mangel på konsensus om hva veiledning er, og store variasjoner i hvordan veiledningen ble gjennomf $\varnothing$ rt. Det var også ulikhet i veilederens rolle og kompetanse, om veiledningen var pålagt eller frivillig, og om den foregikk individuelt eller i gruppe.

Veiledningens setting varierte fra akutte somatiske avdelinger til psykiatri og primærhelsetjenesten.

De fleste studiene var utført i Australia, enkelte i Storbritannia og noen få i Sverige og Danmark.

Forfatterne i denne oversiktsartikkelen (9) mener å påvise mangel på overbevisende evidens av effekt samt manglende konsensus om hva klinisk veiledning er.

\section{Oppsummering av resultatene}

Kun en (5) av de fire systematiske oversiktsartiklene i vårt utvalg påviser evidens for at sykepleiefaglig veiledning har effekt.

\section{三 «Kun en av de fire systematiske oversiktsartiklene i vårt utvalg påviser evidens for at sykepleiefaglig veiledning har effekt.»}


Siden denne artikkelen er innlemmet i artikkelen til Pollock og medarbeidere (9) som ikke påviser evidens for effekt, kan det etter vår vurdering se ut som evidensbegreper kan forstås ulikt, slik vi også påpeker i denne artikkelens introduksjon.

\section{Diskusjon}

\section{Veiledningens kompleksitet}

Dilworth og medarbeidere (8) viser til at sykepleiefaglig veiledning er en kompleks virksomhet med et diffust evidensgrunnlag. Veiledningens kompleksitet er også beskrevet av Reichelt og Rønnestad (10), som hevder at det i veiledning, i likhet med psykoterapiforskning, kan være utfordrende å måle hva som er virksomt.

Situasjoner det reflekteres over i veiledning, kan skrive seg fra et mangfold av pasientmøter fra ulike praksiskontekster og relasjoner.

Selv om deltakerne i en veiledningsprosess har felles profesjonsbakgrunn, representeres et mangfold av personer og relasjoner i veiledningen. Veileder m $\varnothing$ ter en veis $\varnothing \mathrm{ker}$ (sykepleier) som forteller om en pasient eller bruker til en gruppe med kolleger, som igjen har sine erfaringer med en rekke pasienter eller brukere. Veiledningsforskning må, ifølge Reichelt og Rønnestad, ha oppmerksomheten på tre relasjoner: veileder-veis $\varnothing$ ker-bruker, og ikke bare på veilederveisøker (10).

Et eksempel på kompleksiteten i sykepleiefaglig veiledning kan være at deltakerne i en veiledning med forholdsvis lik kontekst for to veiledningsprosesser som skal forskes på, har svært ulik erfaringskompetanse. En novise har et helt annet utgangspunkt for veiledning enn en sykepleie-ekspert. Det samme gjelder en erfaren veileders utgangspunkt i forhold til en nyutdannet veileder med lite erfaring (11).

\section{三 «Det er utfordrende å få til en systematisk og ensrettet forskning innen feltet.»}

Kompleksiteten i veiledning påvirker muligheten for å bygge en felles og ensartet veiledningspraksis. En konsekvens av dette er at det er utfordrende å få til en systematisk og ensrettet forskning innen feltet.

Evidens i form av bevis for at noe har målbare effekter for deltakerne i en veiledningsprosess, vil være vanskelig. 
Hvilken betydning veiledning kan ha for enkeltpersoner, synes derimot å være mere hensiktsmessig å unders $\varnothing \mathrm{ke}$.

Ordets betydning i denne sammenheng kan etter vår erfaring knyttes til evidens forstått som hvilken virkning veiledning kan ha for enkeltpersoner og organisasjoner lokalt. Det utelukker selvsagt ikke at det anvendes systematisk forskning for å påvise slik betydning.

\section{Forståelsen av evidens}

Vurdering av om sykepleiefaglig veiledning har effekt, påvirkes av vår forståelse av evidensbegrepet.

Er det mulig å legge til rette for at variablene i forskning på sykepleiefaglig veiledning blir mere like og dermed enklere å forske på?

Ulike fag har ulike forskningsmetoder. Det kan være et problem at et ensidig positivistisk syn som evidens ofte forutsetter, er begrensende fordi randomiserte kontrollerte studier veier tyngst i forskning $(12,13)$. Krumsvik sier i denne sammenheng at «[å] manipulere dosar av eit medikament $i$ ein eksperimentell studie er mogeleg - å manipulere menneske i interaksjon in situ i sosiale kontekstar er nærast umogeleg» (13).

I søken etter evidens for effekt av veiledning kan det være mere hensiktsmessig å se på hvilken betydning veiledning har for den enkelte.

Francke og de Graaff (7) hevder at sterk vitenskapelig evidens bare fremskaffes når tilfredsstillende design og sammenliknende variabler og metoder blir brukt i forskningen. Anvendt i veiledningsforskning ville det slik vi ser det, kreve at man setter sammen homogene veiledningsgrupper av sykepleiere som arbeider i en noenlunde lik kontekst, og at de gis veiledning ut fra en nøye beskrevet modell når det gjelder tidsrammer, forståelse av veiledningens innhold, metoder og evalueringsformer. Selv i en slik standardisert modell, vil fortsatt både personene og relasjonene fra situasjonsbeskrivelsene i veiledningsprosessene være ulike og påvirke arbeidsformer og opplevelser av utbytte av veiledning. og refleksjoner over sykepleiernes opplevelser og erfaringer.» 
Det som særpreger veiledningsfaget, er samtaler om og refleksjoner over sykepleiernes opplevelser og erfaringer.

Effekten eller betydningen av opplevelser og erfaringer med sykepleiefaglig veiledning kan sannsynligvis utforskes best ved kvalitative metoder som har til hensikt å beskrive og forstå fenomener og sammenhenger.

Til tross for at veiledningsforskning ikke har lange tradisjoner, hevder Severinsson (14) at forskningsresultater fra de siste 20 årene viser at det er av betydning at sykepleiere får anledning til å delta i veiledning som muliggjør refleksjon over den praksis de utøver. Begrepet betydning er knyttet til hva som har verdi og er viktig for oss.

Vi mener at sykepleiefagets helhetlige karakter gjør at refleksjoner kan være knyttet til en helhet som er mer enn summen av delene, og at refleksjoner og vurderinger er kontekstavhengige. Dilworth og medarbeidere (8) fremhever i tillegg den mulighet som sykepleiefaglig veiledning i gruppe gir, for å få frem nyanser i perspektiver i sykepleiernes ulike virksomheter.

\section{Metodekritiske refleksjoner}

Den store variasjonen i terminologi innen sykepleiefaglig veiledning kan ha hatt betydning for hvilke studier vi har funnet og valgt ut. Vi utelukker derfor ikke at potensielt relevante studier er oversett i søket.

Når vi har brukt andres tolkning av studier, kan det være en mulighet for at vi har feiltolket deres forståelse.

En svakhet ved vårt utvalg kan være at studiene vi har valgt, $\mathrm{i}$ noen grad overlapper hverandre. At vi er tre forfattere med felles profesjonsutdanning, lang praktisk erfaring som veiledere og stort engasjement i fagfeltet veiledning, kan være en svakhet ved at vi ikke blir tilstrekkelig kritiske til et fagfelt vi verdsetter høyt. Det kan samtidig være en styrke at vi alle har erfaring og kunnskap om sykepleiefaglig veiledning.

\section{Konklusjon}


Kun en av de fire systematiske oversiktsartiklene påviser evidens for at sykepleiefaglig veiledning har effekt. Mangel på evidens mener vi kan forklares med veiledningens komplekse natur med mange variabler og ulike kontekster.

Oversiktsartiklene viser manglende konsensus om hva sykepleiefaglig veiledning er, og ulike forventninger til målbart utbytte vanskeliggjør påviselig effekt.

\section{三 «Mangel på evidens mener vi kan forklares med veiledningens komplekse natur.»}

Forfatterne av de fire systematiske oversiktsartiklene definerer ikke sin bruk av begrepet evidens. Det påpekes at det til tross for sparsomt med kvantitativ evidens finnes mye kvalitativ forskning som gir innsikt i nytten og betydningen av sykepleiefaglig veiledning.

Vi mener at både evidensbegrepet og veiledningsbegrepet må klargjøres og defineres før man kan vurdere graden av evidens i sykepleiefaglig veiledning.

Ledere bør legge til rette for sykepleiefaglig veiledning fordi veiledningen har betydning for utvikling av fag, ferdigheter og holdninger. Sykepleiere vil ofte få en ny forståelse av situasjoner de har opplevd i sitt arbeid, når de reflekterer sammen med veilederen og kolleger, og gjennom dette kan det oppstå nye sannheter, slik Eriksson antyder. Våre erfaringer er at slike nye sannheter og innsikter også kan ha verdi i møte med andre pasienter og situasjoner. Veiledning gir også sykepleierne mulighet til å gi og motta kollegastøtte, noe som kan redusere stress. Ivaretakelse av sykepleiere som står i krevende situasjoner til daglig, har betydning og kan tjene både arbeidsgiver, arbeidsmiljøet, pasientene og den enkelte sykepleier.

\section{三 «Veiledning gir sykepleierne mulighet til å gi og motta kollegast $\varnothing t t e$, noe som kan redusere stress.»}

Beskrivelse av veiledningens formål, innhold, rammer, arbeidsformer og evalueringsformer samt gode beskrivelser av veilederrollen er vesentlig for at tilbudet om sykepleiefaglig veiledning skal holde god kvalitet og være tilpasset den lokale kontekst og aktuelle deltakere. Nettopp den store variasjonen i hva veiledning er og kan være, nødvendiggjør klargjøring fra veilederen ved oppstart av ny gruppe, for at veiledningen skal tilpasses deltakernes behov.

Tilpasning til lokal kontekst vanskeliggjør måling av effekter, men har kanskje størst betydning for deltakerne. 


\section{Referanser}

1. Norsk Sykepleierforbunds faggruppe for veiledere. Veilederen. Om faglig veiledning i sykepleie. Oslo: Norsk Sykepleierforbunds faggruppen for veiledere; 2014. Tilgjengelig fra: http://digiblad.no/nsf/veilederen/ (nedlastet 02.01.2019).

2. Store norske leksikon. Evidens. [internett]. Oslo: Store norske leksikon; [oppdatert 04.05.2018; sitert 18.08.19]. Tilgjengelig fra: https://snl.no/evidens

3. Eriksson K. Evidens - det sanna, det sköna, det goda och det eviga. I: Martinsen K, Eriksson K, red. Å se og å innse. Om ulike former for evidens. Oslo: Akribe; 2009. s. 35-69.

4. Drangsholt E, Saxlund AM, Vråle GB. Det forskningsbaserte kunnskapsgrunnlaget i sykepleiefaglig veiledning - en litteraturgjennomgang. Faggruppa for veiledere. En internrapport. Upublisert; 2018.

5. Brunero S, Stein-Parbury J. The effectiveness of clinical supervision in nursing; an evidenced based literature review. Australian Journal of Advanced5 Nursing. 2008;25(3):86-94.

6. Proctor B. Training for the supervision alliance. I: Cutcliffe, JR, Hyrkäs K, Fowler J, red. Routledge Handbook of Clinical Supervision, Fundamental International Themes. New York: Routledge; 2011. s. 23-33.

7. Francke AL, de Graaff FM. The effects of group supervision of nurses: A systematic literature review. Int J Nurs Stud. 2012;49(9):1165-79.

8. Dilworth S, Higgins I, Parker V, Kelly B, Turnes J. Finding a way forward: A literature review om current debates around clinical supervision. Contemp Nurse. 2013;45(1):22-32.

9. Pollock A, Campbell P, Deery R, Fleming M, Rankin J, Sloan $\mathrm{G}$, et al. A systematic review of evidence relating to clinical supervision for nurses, midwives and allied health professionals. J Adv Nurs. 2017;73(8):1825-37.

10. Reichelt S, Rønnestad MH. Veiledning i psykoterapeutisk arbeid. Oslo: Universitetsforlaget; 2011. s. 163.

11. Vråle GB. Veiledning når det røyner på ... Oslo:

Gyldendal Akademisk; 2015. s. 47. 
12. Cartwright N. Are RCT's the gold standard? BioSocieties. 2007;2(1):11-20.

13. Krumsvik RJ. Forskningsdesign og kvalitativ metode. Ei innføring. Bergen: Fagbokforlaget; 2014.

14. Severinsson E. Berättelser från handledning - røsterom vanmakt. I: Lasseius E, Severinsson E, red. Hermeneutik i vårdpraxis. Det nära, det flyttinga, det dolda. Malmö: Gleerups; 2014.s. 177-86. 